\title{
Ethnomedicinal uses, phytochemistry and pharmacological properties of the genus, Kirkia
}

\author{
Alfred Maroyi \\ Department of Botany, University of Fort Hare, Private Bag X1314, Alice 5700, South Africa \\ *For correspondence: Email: amaroyi@ufh.ac.za
}

Received: 12 July 2016

Revised accepted: 23 October 2016

\begin{abstract}
Purpose: To review the phytochemical, ethnopharmacology and traditional uses of the Kirkia species throughout their distributional range.

Methods: The information documented in this article is from scientific journals, books, theses and reports obtained from library collections and electronic search engines such as Google, Google scholar, publishing sites such as Elsevier, ScienceDirect, BioMed Central (BMC), PubMed and other scientific database sites such as ChemSpider and PubChem.

Results: Kirkia species are used as herbal remedies for abdominal pain, cholera, cough, snake bites and toothache in East, Central and Southern Africa. There are similarities in the use of Kirkia species as herbal medicines in Central and Southern Africa in terms of plant parts used, herbal preparation, route of administration and dosage. The chemical composition of Kirkia species is dominated by fatty acids, flavonols, isocoumarin, lignans, neolignans, nor-carotenoids, phenols and tannins isolated from leaves, stem bark and roots. Major biological activities demonstrated by Kirkia species include antimicrobial, antioxidant, antiplasmodial and antiplatelet activities.

Conclusion: Kirkia species are valuable herbal medicines with multiple pharmacological effects. Kirkia extracts and their isolates are potential sources of modern medicines following future detailed studies to elucidate their mechanisms of action, toxicity and clinical trials.
\end{abstract}

Keywords: Africa, Ethnobotanical, Isocoumarin, Kirkia species, Lignans, Livelihood needs, Neolignans, Traditional medicine

Tropical Journal of Pharmaceutical Research is indexed by Science Citation Index (SciSearch), Scopus, International Pharmaceutical Abstract, Chemical Abstracts, Embase, Index Copernicus, EBSCO, African Index Medicus, JournalSeek, Journal Citation Reports/Science Edition, Directory of Open Access Journals (DOAJ), African Journal Online, Bioline International, Open-J-Gate and Pharmacy Abstracts

\section{INTRODUCTION}

The monotypic genus Kirkia Oliver is a member of the dicotyledonous family Kirkiaceae Takhtajan which contains six species $[1,2]$. The genus Kirkia was named after Dr John Kirk (1832 - 1922), an English doctor and plant collector, who accompanied Livingstone on his Zambezi expedition [3]. Genus Kirkia is distributed in tropical Africa from Ethiopia and Somalia, south to Madagascar, South Africa and Namibia $[4,5]$. Kirkia acuminata Oliver is the most known and widely distributed species in the genus $[4,6]$. It is semi-deciduous, monoecious medium-sized tree, drought resistant and generally grows in hot and dry areas of Angola, Botswana, Democratic Republic of Congo (DRC), Malawi, Mozambique, Namibia, Zambia, Zimbabwe and South Africa [7].

Kirkia burgeri Stannard is a shrub or small tree divided into two sub-species, K. burgeri subsp. burgeri growing mainly on limestone slopes in Ethiopia. Kirkia burgeri subsp. burgeri is categorized as vulnerable (VUB2ab) (i,ii,iii,iv) on the IUCN Red List [8], primarily because of 
reduction in population size based on decline in area of occupancy, extent of occurrence and/or quality of habitat. Kirkia burgeri subsp. somalensis Stannard is confined to gypsum and anhydrite slopes in northern Somalia where it is categorized as near threatened [9]. Kirkia burgeri subsp. somalensis is generally rare and threatened by habitat degradation, grazing and over-exploitation of the species as a source of construction timber. Kirkia dewinteri Merxm. \& Heineis a small tree up to $10 \mathrm{~m}$ tall endemic to the limestone and dolomite outcrops in the northwestern part of Namibia $[4,6,10]$.

Kirkia dewinteri is categorized as vulnerable (VUD2) on the IUCN Red List in Namibia [11] primarily because of habitat destruction. Ecological research done on $K$. dewinteri showed that the species is generally rare in Namibia, characterized by restricted distributional range and in need of protection from human disturbances and wild fires [10]. Kirkia leandrii (Capuron) Stannard, is a tree, endemic to dry deciduous forest of Bemaraha, central Madagascar [5]. Kirkia tenuifolia is a shrub or small tree which is common or occasional in sandy or stony bushland in Ethiopia, Kenya and Somalia [4]. Kirkia wilmsii Engl. is a deciduous tree endemic to South Africa, found on granite and dolomitic soils in dry bushveld areas or on rocky slopes in Gauteng, Limpopo, Mpumalanga and the North West provinces $[4,6,12]$.
Kirkia species are characterized by fatty acids, flavonols, isocoumarin, lignans, neolignans, norcarotenoids, phenols and tannins which are used medicinally. Preliminary chemical and pharmacological studies done so far on Kirkia species have shown promising results with the possibility that these phytochemical compounds may be responsible for the medicinal uses and biological activities demonstrated by the species. The genus certainly has a high use value. The present review compiles fragmented information on the phytochemical, ethnopharmacological and traditional uses of the Kirkia species, hoping that this information will highlight the ethnopharmacological importance of the genus and will provide baseline information for future researchers intending to do further work on the genus.

\section{Vernacular names and traditional uses}

Kirkia species are known by various vernacular names in different geographical areas in Eastern, Central and Southern Africa (Table 1). Insight into the societal value of Kirkia species in East, Central and Southern Africa can be gained by examining these vernacular names. A survey of literature showed at least 39 vernacular names for $K$. acuminata in Southern Africa (Table 1). Kirkia burgeri subsp. burgeri is known by two vernacular names in Ethiopia (Table 1), while Kirkia tenuifolia is known by one vernacular name in Ethiopia (Table 1).

Table 1: Vernacular names of Kirkia species

\begin{tabular}{|c|c|c|}
\hline Vernacular name(s), Language or geographical region in brackets & Country & Reference(s) \\
\hline $\begin{array}{l}\text { Kirkia acuminata Oliv. } \\
\text { Ivomena, modumela, motsemodumo, mozumina, muzumina (Setswana), white } \\
\text { syringa (English) }\end{array}$ & Botswana & {$[13,14]$} \\
\hline Mtumbu, mtumbwi, mzumba, ntungundwa (Nyanja) & Malawi & [15] \\
\hline Mtumbui (Changana); n’tun'gundua (Sena); poko poko (Tsonga) & Mozambique & [16] \\
\hline Mountain kirkia, white syringa (English) & Namibia & {$[7,10]$} \\
\hline $\begin{array}{l}\text { Modumela (Northern Sotho, Tswana); mvumayila (Tsonga); mubvumala, } \\
\text { mubvumela (Venda); umsila-omhlophe, umsilinga (Zulu), white kirkia, white } \\
\text { seringa (English), witsering (Afrikaans) }\end{array}$ & South Africa & {$[6,17,18]$} \\
\hline $\begin{array}{l}\text { Mtumbwi (Nyanja); mzumba (Senga, Tumbuka); musanta (Tonga), white syringa } \\
\text { (English) }\end{array}$ & Zambia & [19] \\
\hline $\begin{array}{l}\text { Bastard marula, white seringa, white syringa (English); mubvumira, mutsakatidze, } \\
\text { mutuhwa, mutuva (Shona); musanta (Tonga); umvumila, umvumile (Ndebele); } \\
\text { vumaila (Hlengwe, Shangaan) }\end{array}$ & Zimbabwe & {$[7,20-24]$} \\
\hline $\begin{array}{l}\text { Kirkia burgeri Stannard subsp. burgeri } \\
\text { Bisdhugaa (Borana); musdhugaa (Afan Oromo) } \\
\text { Kirkia dewinteri Merxm. \& Heine }\end{array}$ & Ethiopia & {$[25,26]$} \\
\hline $\begin{array}{l}\text { Kaoko syringa (English) } \\
\text { Kirkia tenuifolia Engl. }\end{array}$ & Namibia & [10] \\
\hline $\begin{array}{l}\text { Hudhaa sawwaa (Afan Oromo) } \\
\text { Kirkia wilmsii Engl. }\end{array}$ & Ethiopia & [26] \\
\hline $\begin{array}{l}\text { Bastard pepper tree, mountain kirkia, mountain seringa, wild pepper tree (English); } \\
\text { basterpeperboom, bergsering, slaploot, wildepeperboom (Afrikaans); legaba, } \\
\text { modumela (Northern Sotho) }\end{array}$ & South Africa & {$[6,17]$} \\
\hline
\end{tabular}


Kirkia dewinteri is known by one vernacular name in Namibia (Table 1), while Kirkia wilmsii is known by nine vernacular names in South Africa (Table 1). Local people rarely name plant species that they do not use. The long list of vernacular names for $K$. acuminata and $K$. wilmsii indicates that local people in Central and Southern Africa have an active interest in these species.

The traditional uses of Kirkia species are referred to in many folkloric and ethnobotanical studies done in East, Central and Southern Africa, where the species are still used as primary sources of traditional medicine. A total of 15 human ailments are treated with Kirkia species (Table 2). Abdominal pain, cholera, cough, snake bites and toothache are the most commonly treated human diseases and ailments (Table 2). Many similarities can be recognized when the ethnomedicinal uses of $K$. acuminata are compared in Central and Southern Africa in terms of plant parts used, herbal preparation, route of administration and dosage strength (Table 2). For example, bark infusion of $K$. acuminata is taken as a remedy for abdominal pains in South Africa [27] and Zimbabwe [21]. Root decoction is taken as remedy for cough in Botswana [13,14], Mozambique [28], South Africa [27] and Zimbabwe [21]. Fruit juice of $K$. acuminata is used as a snake bite antidote in Botswana [14] and Zimbabwe [21,23,24]. Such similarities may be ascribed to efficacy of the plant species. This observation is supported by Hossan et al [33] who argued that a plant species is regarded as effective herbal medicine if it is used by many people in different geographical regions for the same disease or ailment.

The most frequently used plant parts are bark (53\%), roots $(23 \%)$, fruits and leaves (12\% each) (Figure 1A). It is well recognized by conservationists that medicinal plants primarily valued for their root parts and those which are intensively harvested for their bark often tend to be the most threatened by over-exploitation [30]. There is need for implementing conservation strategies and mechanisms in East, Central and Southern Africa aimed at conserving Kirkia species, given the fact that $K$. burgeri subsp. burgeri, $K$. burgeri subsp. somalensis and $K$. dewinteri are threatened with extinction [8,9,11]. The population decline of Kirkia species is due to habitat degradation and loss $[8,9,11]$, naturally rare and highly localized in distribution $[10,11]$, over-exploitation of the species [9] and medicinal plant trade. According to Moeng and Potgieter [31], K. wilmsii roots were observed in $44 \%$ of the medicinal plant (muthi) markets in the
Limpopo province, South Africa. Given the widespread usage of Kirkia species in traditional medicine resulting in negative impacts on wild populations calls for conservation strategies aimed at halting or reducing these negative impacts. Therefore, conservation of Kirkia species and the traditional knowledge associated with their medicinal applications are important for sustainable utilization of the species. It is important to take concrete conservation measures aimed at protecting the species against over-exploitation and habitat loss. Kirkia remedies are often utilized in the form of decoction or infusion (60.9\%), bark powder mixed with food (17.4\%), ointments or paste $(13.0 \%)$, body and tooth wash (4.3\%) (Figure 1B). Most (70.6\%) of the preparations are prescribed orally (Table 2). All Kirkia remedies are used as monotherapies (Table 2).

In addition to the medicinal uses, the swollen roots of $K$. acuminata, $K$. tenuifolia and $K$. wilmsii are used as sources of water during drought $[5,7,17,20,34]$. Leaves, seeds and twigs of $K$. acuminata and leaves of $K$. burgeri subsp. burgeri and $K$. wilmsii are browsed by game and livestock $[17,25,45]$. The timber or wood of $K$. acuminata and $K$. wilmsii are used for construction poles, carving household utensils and furniture [12,40]. Fibre obtained from the bark, young shoots and roots of $K$. acuminata and $K$. wilmsii used for weaving $[6,7,12,17]$. Kirkia acuminata is grown around homestead boundaries as a barrier or hedge or live fence and also as an ornamental and shade tree. In South Africa, Zambia and Zimbabwe, $K$. acuminata is commonly used as live fence around fields, gardens, homesteads and schools as a form of protection against animals; around enclosures (kraals) for livestock. The poles of $K$. acuminata take root and grow easily [12] explaining the high proportion of study households (23\%) with the species growing around their homesteads as live fence in Malawi [41].

\section{Phytochemical studies}

Over the last 50 years, there have been numerous attempts to scientifically validate the ethnomedicinal uses of Kirkia species. However, most of these studies concentrated on $K$. acuminata, possibly because of its availability when compared with other Kirkia species which are highly localized with restricted distribution. Some ethnopharmacological studies have also been carried out on K. wilmsii, a South African endemic species. Based on literature records documenting traditional and potential medicinal uses of $K$. acuminata and $K$. wilmsii, researchers 
have also investigated their phytochemical and pharmacological properties aimed at identifying the compounds responsible for their wide use in traditional medicine. Multiple classes of phytochemicals including tannins [43,46,47], quercetin, caffeic acid, ellagic acid and gallic acid [54], flavonol, lignans, neolignans, norcarotenoids and isocoumarin [49], phenols, acetic acid, propionic acid, iso butyric acid, butyric acid and valeric acid [50] have been identified from $K$. acuminata and $K$. wilmsii leaves, roots, seeds and twigs.

Fresh leaves and twigs of $K$. acuminata have a wide variety of nutrients such as minerals, fibre, proteins and fat $[43,46,47]$. Kirkia acuminata leaves, seeds and twigs are a good source of minerals such as calcium, copper, iron, magnesium, manganese, phosphorus, sodium and zinc $[43,45,47]$. According to Aganga and Mosase [43], K. acuminata seeds have adequate quantities of phosphorus, calcium, magnesium, potassium, iron and copper required for beef, sheep and goat growth and production, while the content of sodium, manganese and zinc are below the recommended levels required by ruminants for growth and productivity. Some of these nutrients are present in low concentrations, but may have significant impact on animal health as both $K$. acuminata and $K$. wilmsii are important stock feed in southern Africa $[17,20,43,46,47]$.

Nooteboom [48] isolated quercetin, caffeic acid, ellagic acid and large quantities of gallic acid from hydrolysed leaf extracts of K. wilmsii (Figure 2). Similarly, Gemeda and Hassen [50] isolated acetic acid, propionic acid, iso butyric acid, butyric acid and valeric acid from both $K$. acuminata and $K$. wilmsii leaves and young stems. Diakanamwa et al [51] isolated 3,3'-di-Omethylellagic acid 4-O- $\beta$-D-xylopyranoside from $K$. acuminata roots. From $K$. acuminata hexane stem bark extract, Mulholland et al [49] isolated (+)-(6S,7E,9R)-blumenol $\mathrm{A}$ and $(+)-(6 S, 7 E)-$ dehydrovomifoliol and $(+)$-de-Omethyllasiodiplodin. The methanol stem bark extract of $K$. acuminate yielded neolignan, (-)4',9,9'-trihydroxy-3'-methoxy-3.0.8',4.0.7'-

neolignan while dichloromethane extract yielded (+)-dihydrodehydrodiconiferyl alcohol, (+)lyoniresinol and (-)-ent-isolariciresinol [49]. The dichloromethane extract of K. wilmsii yielded (+)(6S,7E,9R)-blumenol A, $\quad(+)-(6 S, 7 E)-$ dihydrovomifoliol, (+)-4-ethanone-3,4-dihydro6,8-dihydroxy-5-methylisocoumarin and (+)$(2 R, 3 R)-7-O-m e t h y l a r o m a d e n d r i n . \quad$ Although there is a possibility that these phytochemical compounds may be responsible for the medicinal uses and biological activities demonstrated by both $K$. acuminata and $K$. wilmsii, but no studies were found in literature with details of biological activities of these compounds isolated from Kirkia species.

\section{Pharmacological activities}

Some of the pharmacological activities of $K$. acuminata and $K$. wilmsii reported in literature correlate with some of their ethnomedicinal uses listed in Table 2. While some of these pharmacological activities may not relate directly to their ethnomedicinal uses, they may provide some insight into potential therapeutic value and bioactive properties of $K$. acuminata and $K$. wilmsii. The biological activities that have been reported so far include antimicrobial [52-55], antioxidant [56], antiplasmodial [36] and antiplatelet [56] activities.
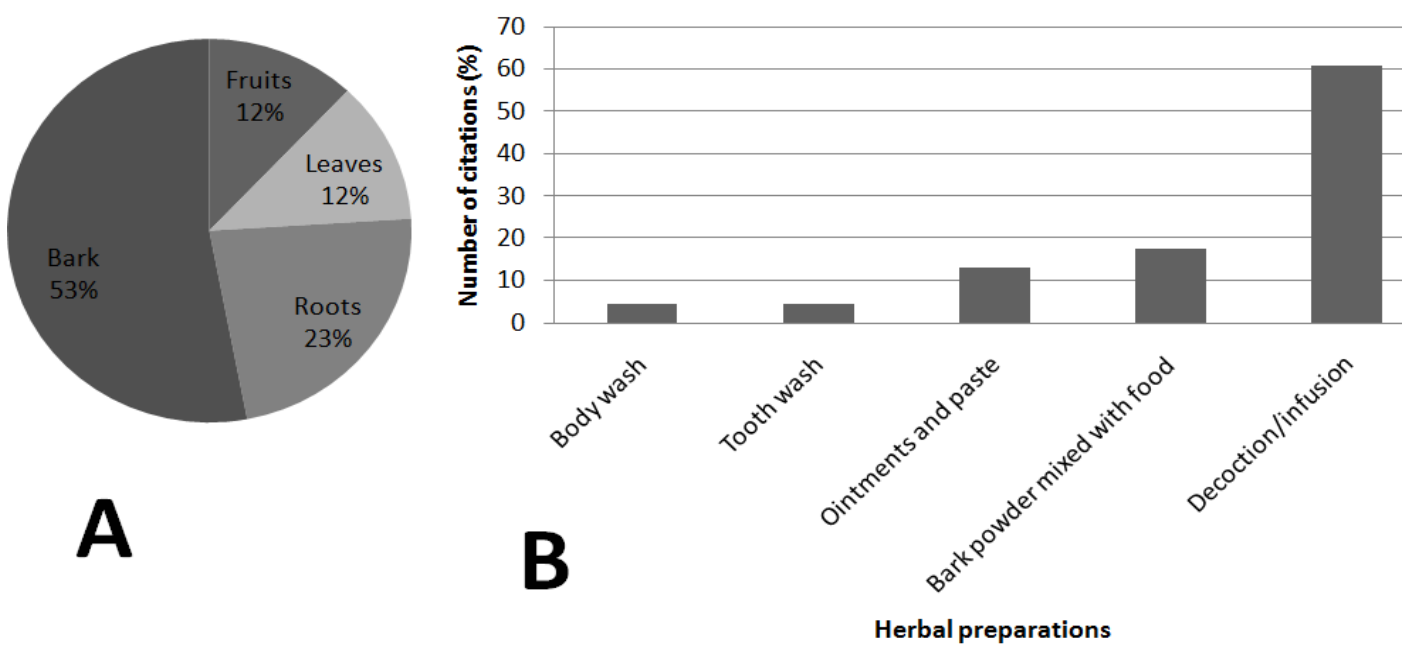

Figure 1: Preparation of Kirkia herbal medicines in East, Central and Southern Africa. A: Plant parts used and B: Herbal preparations 
Table 2: Traditional uses of Kirkia species

\begin{tabular}{|c|c|c|}
\hline Use & Plant part(s) used and preparation & $\begin{array}{l}\text { Country practised and } \\
\text { reference(s) }\end{array}$ \\
\hline \multicolumn{3}{|l|}{ Medicinal uses } \\
\hline Abdominal pain & Bark infusion taken by mouth & South Africa [27], Zimbabwe [21] \\
\hline Antiemetic & Bark infusion taken by mouth & Zimbabwe [21] \\
\hline Backache & Bark infusion taken by mouth & Zimbabwe [32] \\
\hline Cholera & Bark decoction drunk or bark powder mixed with food & Zimbabwe $[22,24]$ \\
\hline Constipation & Bark decoction drunk or bark powder mixed with food & Zimbabwe $[22,24]$ \\
\hline Cough & Root decoction taken by mouth & $\begin{array}{l}\text { Botswana [13,14], Mozambique } \\
\text { [28], South Africa [27], Zimbabwe } \\
\text { [21] }\end{array}$ \\
\hline Diarrhea & Bark decoction drunk or bark powder mixed with food & Zimbabwe $[22,24]$ \\
\hline Dysentery & Bark decoction drunk or bark powder mixed with food & Zimbabwe $[22,24]$ \\
\hline Fever & Not specified & Zambia [33] \\
\hline Snake bite antidote & Fruit juice applied on bitten part & $\begin{array}{l}\text { Botswana [14], Zimbabwe } \\
{[21,23,24]}\end{array}$ \\
\hline To bring luck & Powdered inner bark added to bathing water & Botswana [13] \\
\hline To fatten babies & Baby washed with root infusion & Zimbabwe [21] \\
\hline Toothache & Tooth washed with decoction of pulverized roots & Zimbabwe $[4,7]$ \\
\hline Toothache & Burnt root powder rubbed on painful tooth & Zambia [20] \\
\hline Vomiting & Bark infusion is taken by mouth & South Africa [27] \\
\hline Wounds & Fruit juice applied to wounds & Zimbabwe $[20,23,24]$ \\
\hline \multicolumn{3}{|l|}{ K. tenuifolia } \\
\hline cholera & Bark decoction is taken by mouth & Somalia [34] \\
\hline \multicolumn{3}{|l|}{ K. wilmsii } \\
\hline Diabetes mellitus & Root juice taken orally & South Africa [35] \\
\hline Fever & Leaf decoction & South Africa [36] \\
\hline Hypertension & Roots eaten raw & South Africa $[37,38]$ \\
\hline Malaria & Bark/leaf decoction & South Africa [36,39] \\
\hline Toothache & Tooth washed with root decoction & South Africa [40] \\
\hline \multicolumn{3}{|l|}{$\begin{array}{l}\text { Other uses } \\
\text { K. acuminata }\end{array}$} \\
\hline Charcoal & Wood made into charcoal & Malawi [7] \\
\hline $\begin{array}{l}\text { Hedge, ornamental, } \\
\text { shade }\end{array}$ & $\begin{array}{l}\text { Grown and managed as hedge, cattle enclosure, live fence, } \\
\text { ornamental, stock shade and shade tree in home gardens }\end{array}$ & $\begin{array}{l}\text { Malawi [15,41], South Africa [17], } \\
\text { Zambia [20], Zimbabwe [7] }\end{array}$ \\
\hline Religious significance & Often planted in grave-yards in memory of the deceased & Zambia [20] \\
\hline Religious significance & $\begin{array}{l}\text { Shona people believe that ancestral spirits live in } K \text {. } \\
\text { acuminata branches }\end{array}$ & Zimbabwe [42] \\
\hline Source of water & Swollen roots are used as a source of water during drought & $\begin{array}{l}\text { South Africa [17], Zambia [20], } \\
\text { Zimbabwe [7] }\end{array}$ \\
\hline Stock feed & Leaves and seeds browsed by game and livestock & $\begin{array}{l}\text { Botswana [43], Zambia [20], } \\
\text { Zimbabwe [44] }\end{array}$ \\
\hline Timber, wood & For construction poles; wood for carving and furniture & $\begin{array}{l}\text { Botswana [14], Malawi [41], South } \\
\text { Africa [17], Zambia [20], Zimbabwe } \\
\text { [7] }\end{array}$ \\
\hline Weaving & Root bark made into cloth & Zambia $[19,20]$, Zimbabwe $[4,7]$ \\
\hline \multicolumn{3}{|c|}{ K. burgeri subsp. burgeri } \\
\hline Fodder & Browsed by livestock & Ethiopia $[25,45]$ \\
\hline \multicolumn{3}{|l|}{ K. tenuifolia } \\
\hline \multicolumn{3}{|l|}{ K. wilmsii } \\
\hline Garden plant & An excellent garden plant which tolerates mild frost & South Africa [6] \\
\hline Source of water & Swollen roots are used as a source of water during drought & South Africa $[5,17]$ \\
\hline Stock feed & $\begin{array}{l}\text { Foliage often cut as goat fodder and eaten by other wild } \\
\text { animals }\end{array}$ & South Africa [17] \\
\hline Timber, wood & Wood used for making household utensils & South Africa $[12,40]$ \\
\hline Weaving & $\begin{array}{l}\text { Fibre obtained from the bark, young shoots and roots } \\
\text { is strong and used for weaving }\end{array}$ & South Africa $[5,6,12,17]$ \\
\hline
\end{tabular}


<smiles></smiles>

Quercetin<smiles>O=C(O)/C=C/c1ccc(O)c(O)c1</smiles>

Caffeic acid<smiles>CCCC(=O)O</smiles>

Butyric acid<smiles>CCCCC(=O)O</smiles>

Valeric acid

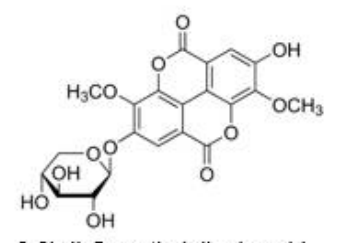

3.3'-di-O-methylellagic acid 4-O- $\beta$-D-xylopyranoside<smiles>COc1cc(C2Oc3c(O)cc(CCCO)cc3C2CO)ccc1O</smiles>

(+)-dibydrodehydrodiconiferxl alcohol<smiles>COc1cc([C@H]2c3cc(O)c(OC)cc3C[C@H](CO)C2CO)ccc1O</smiles>

(+)-Lyoniresinol<smiles>O=c1oc2c(O)c(O)cc3c(=O)oc4c(O)c(O)cc1c4c23</smiles>

Ellagic acid<smiles>O=C(O)c1cc(O)c(O)c(O)c1</smiles>

Gallic acid<smiles>CC1=CC(=O)CC(C)(C)[C@]1(C)/C=C/C(C)O</smiles>

$(+)=(6 \mathrm{~S}, 7 E, 9 R)$-blumenol A

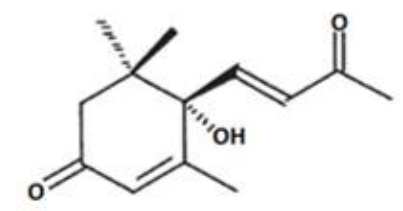

$(+)=(6 S, 7 E)$-debydrovomifoliol<smiles>CC(=O)O</smiles>

Acetic acid<smiles>CCC(=O)O</smiles>

Propionic acid<smiles>CC(C)C(=O)O</smiles>

Iso butyric acid<smiles>CC1CCCCCCCc2cc(O)cc(O)c2C(=O)O1</smiles>

(+)-de=0-methyllasiodiplodin<smiles>C=C1c2c(C)cc(O)cc2O[C@H](c2ccc(I)cc2)[C@@H]1C</smiles>

(-)-4',2.2'-trihydroxy-3'-methoxy-3.0.8', 4.07'-neolignan<smiles>COc1cc([C@@H]2c3c(cc(OC)c(O)c3O)C[C@H](CO)[C@H]2CO)cc(OC)c1O</smiles>

(-)-ent-isolariciresinol<smiles>CC(=O)C1COC(=O)c2c(O)cc(O)c(C)c21</smiles>

$(+)=(2 R, 3 R)-7-0$-methylaromadendrin<smiles>COc1ccc(C2Oc3ccc(CCCO)cc3OC2CO)cc1O</smiles>

(+)-4-ethanone-3.4-dihydro-6,

8-dihydroxy-5-methylisocoumarin

Figure 2: Chemical structures of compounds isolated from leaves, stem bark and roots of Kirkia species 


\section{Antimicrobial activity}

One of the most common ethnomedicinal uses of Kirkia species, $K$. acuminata, $K$. tenuifolia and $K$. wilmsii is in the treatment of a wide range of infectious diseases caused by microorganisms. Such diseases or ailments include symptoms such as cholera [22,24,34], diarrhoea [22,24], dysentery [22,24], fever and malaria [33,36,39], toothache $[4,7,20]$ and wounds $[21,23,24]$. Such wide use of Kirkia species against microbial infections in traditional medicine prompted Masoko [54] to evaluate antibacterial effects of acetone, dichloromethane, hexane and methanol leaf extracts of $K$. acuminata against Enterococcus faecalis, Escherichia coli, Pseudomonas aeruginosa and Staphylococcus aureus with ampicillin as the positive control. In this study, E. faecalis was the most sensitive microorganism with average MIC value of 0.1 $\mathrm{mg} / \mathrm{ml}$ followed by $E$. coli $(0.31 \mathrm{mg} / \mathrm{mL})$ while $S$. aureus and $P$. aeruginosa were resistant with MIC values of $0.97 \mathrm{mg} / \mathrm{mL}$ ) and $1.25 \mathrm{mg} / \mathrm{ml}$ respectively [54]. Similarly, Mmushi et al [52] evaluated acetone, dichloromethane, hexane and methanol leaf extracts of $K$. acuminata against Mycobacterium smegmatis using rifampicin as a positive control. The acetone, dichloromethane, hexane and methanol extracts demonstrated antimycobacterial activity with MIC values ranging between 0.31 to $0.63 \mathrm{mg} / \mathrm{mL}$ against $M$. smegmatis [52].

Suleiman et al $[53,57]$ evaluated the hexane, acetone, dichloromethane and methanol extracts of $K$. wilmsii against Enterococcus faecalis, Escherichia coli, Pseudomonas aeruginosa and Staphylococcus aureus using the bioautographic procedure and a two-fold serial microdilution method. The authors found 18 inhibition bands against bacteria. Suleiman et al $[53,57]$ also evaluated the hexane, acetone, dichloromethane and methanol extracts of $K$. wilmsii against Aspergillus fumigatus, Candida albicans, Cryptococcus neoformans, Microsporum canis and Sporothrix schenckii using the bioautographic procedure and a two-fold serial microdilution method. The authors found 11 inhibition bands against fungi. The acetone, dichlomethane, hexane and methanol extracts of $K$. wilmsii had antibacterial and antifungal activities with MIC values ranging from 0.07 to $2.50 \mathrm{mg} / \mathrm{mL}$ against the tested bacteria and fungi $[53,57]$. The leaves of the $K$. wilmsii further showed biological activity against the animal fungal pathogen Aspergillus fumigatus and the MIC ranged from 0.17 to $2.11 \mathrm{mg} / \mathrm{mL}$ [57]. In another study, Chigayo et al [55] evaluated the antimicrobial activity of aqueous root extracts of $K$. wilmsii using an HPLC gradient elution method with kanamycin as the positive control. The extracts showed antimicrobial activities against Aeromonas hydrophilia, Candida albicans, Enterobacter aerogenes, Escherichia coli, Proteus mirabilis, Salmonella typhi, Shigella dysenteriae, Staphylococcus aureus, Vibrio cholerae with minimum inhibitory concentration (MIC) ranging from $0.08 \mathrm{mg} / \mathrm{mL}$ to $3.445 \mathrm{mg} / \mathrm{ml}$. Results of these studies implies that $K$. acuminata and K. wilmsii may be used as a broad spectrum antibiotics.

\section{Antiplasmodial activity}

Clarkson et al [36] evaluated leaf extracts of $K$. wilmsii against Plasmodium falciparum using the parasite lactate dehydrogenase (pLDH) assay. The dichloromethane/methanol (1:1) was highly active and showed promising antiplasmodial activity with $\mathrm{IC}_{50}$ of $3.7 \mu \mathrm{g} / \mathrm{mL}$, while water extra showed a weak activity with $\mathrm{IC}_{50}$ of $>100 \mu \mathrm{g} / \mathrm{mL}$ [36]. These pharmacological evaluations are important as the bark and leaf decoctions of $K$. wilmsii are used as herbal medicine for fever and malaria in South Africa $[36,39]$. Such pharmacological evaluations are also important for future research focusing on control and management of parasites and mosquito vectors in the tropics.

\section{Antioxidant and antiplatelet activities}

Extracts of $K$. wilmsii exhibited antioxidant properties in the qualitative assay using DPPH with $\mathrm{EC}_{50}$ value of $3.57 \pm 0.41 \mu \mathrm{g} / \mathrm{mL}$ [56]. In the quantification of antioxidation using ABTS, the extracts of $K$. wilmsii showed low antioxidant activities with respect to TEAC values of 0.67. Kirkia wilmsii showed low antiplatelet activity with $E_{50}$ value of $0.22 \pm 0.02 \mu \mathrm{g} / \mathrm{mL}$ [56]. The documented antioxidant and antiplatelet activities of $K$. wilmsii may be attributed to the presence of phytochemicals since compounds such as flavonols and phenolics are known to have antioxidant properties [58] and also lower the risk of cancer, heart diseases, hypertension and stroke [59]. Detailed anti-hypertensive studies of $K$. wilmsii are recommended based as ethnopharmacological studies by Semenya and Potgieter [37] revealed that $97 \%$ of traditional healers in the Limpopo province, South Africa use $K$. wilmsii in a similar manner as hypertension remedy in terms of herbal preparation, route of administration and dosage strength.

Trop J Pharm Res, November 2016; 15(11): 2513 


\section{Toxicity studies}

Kirkia wilmsii extracts showed comparably low toxicity when compared with the reference agent berberine (cytotoxic agent) with hemagluttination assay titre value of 0.80 and agglutination value of $1.25 \mathrm{mg} / \mathrm{mL}$ [56]. Toxicological evaluations carried out so far on Kirkia are preliminary considering their widespread usage as herbal medicines in southern Africa. It is important to ascertain any toxicological effects that can occur as a result of chronic of sub-chronic usage of Kirkia species, and the different plant parts should be tested against a wide range of cell lines as well as using other in vitro toxicological assays and in vivo studies.

\section{CONCLUSION}

Of the six Kirkia species, only $K$. acuminata, $K$. wilmsii and to some extent $K$. tenuifolia have been studied so far under different ethnobotanical and ethnopharmacological aspects. The others are either threatened with extinction or are highly localized, naturally rare and in need of human intervention to save them from extinction. There is therefore need to develop conservation strategies and mechanisms for Kirkia species that are threatened with extinction as well develop micropropagation protocols as an alternative and viable means to provide sufficient plants to meet the herbal medicine needs and at the same time protecting the natural populations.

From literature, it is clear that both $K$. acuminata and $K$. wilmsii have been used for centuries in southern Africa as herbal medicines for microbial infections in humans and scientific studies carried out so far have validated some of their traditional antimicrobial uses. Up to now, only a few pharmacological studies directly dealing with the documented traditional uses of $K$. acuminata and $K$. wilmsii have been performed. Phytochemical studies led to the identification of a large number of fatty acids, flavonols, isocoumarin, lignans, neolignans, norcarotenoids, phenols and tannins. Most of these phytochemicals have not been evaluated, therefore, these compounds must be evaluated biologically in more detail. Further investigations should focus on phytochemical studies of these isolated compounds and try to link such pharmacological properties to documented ethnomedicinal uses.

Concerning toxicological information, no significant data are reported. A weak cytotoxic activity is described only for K. wilmsii [56]. Future research should focus on assessing biological and toxicological aspects of the leaves, stem bark and roots of Kirkia species used as herbal medicines as well as both their bioactive extracts and isolated compounds. There is no doubt that results presented in this review may provide useful clues to promote further investigations of ethnopharmacological properties as well as potential use of phytochemicals isolated from Kirkia species.

\section{DECLARATIONS}

\section{Acknowledgement}

Financial support of this work by the National Research Foundation (NRF) and Govan Mbeki Research and Development Centre (GMRDC), University of Fort Hare is gratefully acknowledged.

\section{Conflict of Interest}

No conflict of interest associated with this work.

\section{Contribution of Authors}

The authors declare that this work was done by the authors named in this article and all liabilities pertaining to claims relating to the content of this article will be borne by them.

\section{Open Access}

This is an Open Access article distributed under the terms of the Creative Commons Attribution License, which permits unrestricted use, distribution, and reproduction in any medium, provided the original work is properly credited.

\section{REFERENCES}

1. Bachelier JB, Endress PK. Floral structure of Kirkia (Kirkiaceae) and its position in Sapindales. Ann Bot 2008; 102: 539-550.

2. Muellner AN. Kirkiaceae. In: Kubitzki K (Ed.), The families and genera of vascular plants: Flowering plants eudicots. Springer-Verlag, Berlin; 2011; pp. 180-185.

3. Palmer E, Pitman P. Trees for southern Africa covering all known indigenous species in Republic of South Africa, South West Africa, Botswana, Lesotho and Swaziland. A.A. Balkema, Cape Town; 1972.

4. Stannard BL. A revision of Kirkia (Simaroubaceae). Kew Bulletin 1981; 35: 829-839.

Trop J Pharm Res, November 2016; 15(11): 2514 
5. Heywood VH, Brummit RK, Culham A, Soberg $O$. Flowering plant families of the world. Firefly Books, Richmond Hill; 2007.

6. van Wyk B-E, van Wyk P. Field guide to trees of southern Africa. Struik, Cape Town; 1997.

7. Brink M. Kirkia acuminata Oliv. In: Louppe D, OtengAmoako AA, Brink M (Eds.), Plant Resources of Tropical Africa 7: Timbers 1. Backhuys Publishers, Leiden; 2008. pp. 344-345.

8. Vivero JL, Kelbessa E, Demissew S. The Red List of endemic trees and shrubs of Ethiopia and Eritrea. Fauna and Flora International, Cambridge; 2010.

9. Thulin M. Kirkia burgeri ssp. somalensis. The IUCN Red List of Threatened Species 1998: e.T35170A9916069. http://dx.doi.org/10.2305/IUCN.UK.1998.RLTS.T35170A 9916069.en; 1998. Accessed on 10 March 2016.

10. Cunningham PL, Adank W, Esterhuizen A. Notes on some aspects of the ecology of Kirkia dewinteri Merxm. \& Heine, (Kaoko Syringa) from the Kunene Region, Namibia. Dinteria2004; 29: 19-26.

11. Craven P, Loots S. Namibia. In: Golding JS (Ed.), Southern African plant Red Data Lists. Southern African Botanical Diversity Network Report No. 14, SABONET, Pretoria; 2002. pp. 61-92.

12. Palgrave KC. Trees of Southern Africa. Struik Publisher, Cape Town, 2000.

13. Hedberg I, Staugard F. Traditional medicine in Botswana: Traditional medicinal plants. Ipelegeng Publishers, Gaborone; 1989.

14. Mothanka DMT, Nthoiwa GP. Ethnobotanical survey of medicinal plants of Tswapong North, in Eastern Botswana: A case of plants from Mosweu and Seolwane villages. Eur J Med Plants 2013; 3: 10-24.

15. Theu MPKJ. Declining use of indigenous knowledge and technologies as a contribution factor to deforestation. Forestry Research Institute of Malawi, Zomba, Malawi. Community-based management of Miombo Woodlands in Malawi. Proceedings of a National Workshop, Sun and Sand Holiday Resort, Mangochi, Malawi, 27-29 September 1999.

16. Palgrave $M C$, van Wyk, $B-E$, Jordaan $M$, White JA, Sweet $P$. A reconnaissance survey of the woody flora and vegetation of the Catapú logging concession, Cheringoma District, Mozambique. Bothalia 2007; 37: 57-73.

17. Schmidt E, Lotter M, McCleland W. Trees and shrubs of Mpumalanga and Kruger National Park. Jacana Media, Johannesburg; 2002.

18. Mbambezeli G. Kirkia acuminata Oliv. http://www.plantz africa.com; 2004. Accessed on 2 April 2016.

19. Scudder T. The ecology of the Gwembe Tonga. Manchester University Press, Manchester; 1962.

20. Simute S, Phiri CL, Tengnäs B. Agroforestry extension manual for eastern Zambia. Regional Land Management Unit (RELMA), Swedish International Development Cooperation Agency (Sida). Regional Land Management Unit (RELMA) Technical Handbook Series, Nairobi; 1998
21. Gelfand M, Mavi S, Drummond RB, Ndemera B. The traditional medical practitioner in Zimbabwe: His principles of practice and pharmacopoeia. Mambo Press, Gweru; 1985.

22. Chigora $P$, Masocha $R$, Mutenheri $F$. The role of indigenous medicinal knowledge (IMK) in the treatment of ailments in rural Zimbabwe: The case of Mutirikwi communal lands. J Sustain Dev Afr 2007; 9: 26-43.

23. Maroyi A. Ethnobotanical study of medicinal plants used by people in Nhema communal area, Zimbabwe. J Ethnopharmacol 2011; 136: 347-354.

24. Maroyi A. Traditional use of medicinal plants in southcentral Zimbabwe: review and perspectives. J Ethnobiol Ethnomed 2013; 9:31.

25. Gemedo-Dalle T, Maass BL, Isselstein J. Plant biodiversity and ethnobotany of Borana pastoralists in southern Oromia, Ethiopia. Econ Bot 2005; 59: 43-65.

26. Didita M, Nemomissa S, Gole, TW. Floristic and structural analysis of the woodland vegetation around Dello Menna, Southeast Ethiopia. J Forestry Res 2010; 21(4): 395-408.

27. van Wyk B-E, Wink M. Medicinal plants of the world. Briza Publications, Pretoria; 2004.

28. Gelfand M. Livingstone the doctor: His life and travels. Blackwell, Oxford; 1957.

29. Hossan MS, Hanif A, Agarwala B, Sarwar MS, Karim M, Rahman MT, Jahan R, Rahmatullah M, Traditional use of medicinal plants in Bangladesh to treat urinary tract infections and sexually transmitted diseases. Ethnobot Res Appl 2010; 8: 61-74.

30. Flatie $T$, Gedif $T$, Asres $K$, Gebre-Mariam $T$. Ethnomedicinal survey of Berta ethnic group Assosa Zone, Benishangul-Gumuz regional state, mid-west Ethiopia. J Ethnobiol Ethnomed 2009; 5:14.

31. Moeng ET, Potgieter MJ. The trade of medicinal plants by muthi shops and street vendors in the Limpopo Province, South Africa. J Med PI Res 2011; 5(4): 558564.

32. Gelfand M. Medicine and magic of the Mashona. Juta, Cape Town; 1956.

33. Fowler DG. Traditional fever remedies: A list of Zambian plants. Available from: http://www.giftsofhealth.org /ritam/news/Traditional_Fever_remedie1.pdf; 2006. Accessed on 24 April 2016.

34. Bosch CH. Kirkia tenuifolia Engl. In: Schmelzer GH, Gurib-Fakim A (Eds.), Plant Resources of Tropical Africa 11(1): Medicinal plants. Backhuys Publishers, Leiden; 2008. pp. 358-359.

35. Semenya S, Potgieter MJ, Erasmus L. Ethnobotanical study of medicinal plants used by Bapedi healers to treat diabetes mellitus in the Limpopo province, South Africa. J Ethnopharmacol 2012; 141: 440-445.

36. Clarkson C, Maharaj VJ, Crouch NR, Grace MO, Pillay P, Matsabisa MG, Niresh B, Smith PJ, Folb PI. In vitro antiplasmodial activity of medicinal plants native to or naturalized in South Africa. J Ethnopharmacol 2004; 92: 177-191.

Trop J Pharm Res, November 2016; 15(11): 2515 
37. Semenya SS, Potgieter MJ. Kirkia wilmsii: A Bapedi treatment for hypertension. S Afr J Bot 2015; 100: 228232.

38. Semenya SS, Potgieter MJ, Tshisikhawe MP. Use, conservation and present availability status of ethnomedicinal plants of Matebele village in the Limpopo Province, South Africa. Afr J Biotechn 2013; 12: 2392-2405.

39. Maroyi A, Mosina GKE. 2014. Medicinal plants and traditional practices in peri-urban domestic gardens of the Limpopo province, South Africa. Indian J Indig Knowl2014; 13: 665-672.

40. Venter F, Venter J-A. Making the most of indigenous trees. Briza Publications, Pretoria; 1996.

41. Abbot JIO, Homewood K. A history of change: causes of miombo woodland decline in a protected area in Malawi. J Appl Ecol 1999; 36: 422-433.

42. Mavi S, Shava S. Traditional methods of conserving medicinal plants in Zimbabwe. BGCNews 2. http://www.bgci.org/worldwide/article/0347; 1997. Accessed on 5 May 2016.

43. Aganga AA, Mosase KW. Tannin content, nutritive value and dry matter digestibility of Lonchocarpus capassa, Zizyphus mucronata, Sclerocarya birrea, Kirkia acuminata and Rhus lancea seeds. Animal Feed Sci Technol 2001; 91: 107-113.

44. Sibanda HM, Ndlovu LR. The value of indigenous browsable tree species in livestock production in semiarid communal grazing areas of Zimbabwe. Proceedings of the Joint Feed Resources Network Workshop, Mar. 48, African Feed Research Network, Addis Ababa; 1992.

45. Gemedo-Dalle T, Isselstein J, Maass BL. Indigenous ecological knowledge of Borana pastoralists in southern Ethiopia and current challenges. Int J Sust Develop World Ecol 2005; 12: 1-18.

46. Aganga AA, Adogla-Bessa T. Dry matter degradation, tannin and crude protein contents of some indigenous browse plants of Botswana. Arch Zootec 1999; 48: 7983.

47. Aganga AA, Adogla-Bessa T, Omphile UJ, Tshireletso $K$. Significance of browses in the nutrition of Tswana goats. Arch Zootec 2000; 49: 469-480.

48. Nooteboom HP. The taxonomic position of Irvingioideae, Allantospermum Forman and Cyrillopsis Kuhlm. Adansonia 1967; 11: 161-168.
49. Mulholland DA, Cheplogoi P, Crouch NR. Secondary metabolites from Kirkia acuminata and Kirkia wilmsii (Kirkiaceae). Biochem Syst Ecol 2003; 31: 793-797.

50. Gemeda BS, Hassen A. Effect of tannin and species variation on in vitro digestibility, gas and methane production of tropical browse plants. Asian Australas $J$ Anim Sci 2015; 28: 188-199.

51. Diakanamwa C, Diallo B, Vanhaeelen-Fastre M. 3,3'-DiO-methylellagic acid 4-O-alpha;-D-xylopyranoside from Kirkia acuminata roots. Fitoterapia 1991; 62: 87-88.

52. Mmushi TJ, Masoko P, Mdee LK, Mokgotho MP, Mampuru LJ, Howard RL. Antimycobacterial evaluation of fifteen medicinal plants in South Africa. Afr J Trad Complement Altern Med 2010; 7: 34-39.

53. Suleiman MM, McGaw LJ, Naidoo V, Eloff JN. Detection of antimicrobial compounds by bioautography of different extracts of leaves of selected South African tree species. Afr J Trad Complement Altern Med 2010; 7: 64-78.

54. Masoko P. Ethnobotanical study of some selected medicinal plants used by traditional healers in Limpopo Province, South Africa. Amer J Res Comm 2013; 1: 823.

55. Chigayo K, Mojapelo PEL, Bessong P, Gumbo JR. The preliminary assessment of anti-microbial activity of HPLC separated components of Kirkia wilmsii. Afr J Trad Complement Altern Med 2014; 11: 275-281.

56. Suleiman MM, Bagla V, Naidoo V, Eloff JN. Evaluation of selected South African plant species for antioxidant, antiplatelet and cytotoxic activity. Pharmac Biol 2010; 46: 643-650.

57. Suleiman MM, McGaw LJ, Naidoo V, Eloff JN. Evaluation of several tree species for activity against the animal fungal pathogen Aspergillus fumigates. S Afr J Bot 2010; 76: 64-71.

58. Ndhlala AR, Mupure C, Chitindingu K, Benhura MA, Muchuweti M. Antioxidant potentials and degrees of polymerization of six wild fruits. Scientific Res Essay 2006; 1: 87-92.

59. Lako J, Trenerry VC, Wahlqvist M, Wattanapenpaiboon $N$, Sotheeswaran S, Premier R. Phytochemical flavonols, carotenoids and antioxidant properties of a wide selection of Fijian fruit, vegetables and other readily available foods. Food Chem 2007; 101: 17271741. 